\title{
PRESERVATION POTENTIAL OF COMBINATION OF CLOVE AND LEMON BASIL ESSENTIAL OILS ON FRESH CHICKEN MEAT
}

\author{
Dwi Hartanti ${ }^{1)^{*}}$, Nur Annisa Septiyaningrum ${ }^{1)}$, Alwani Hamad ${ }^{2)}$

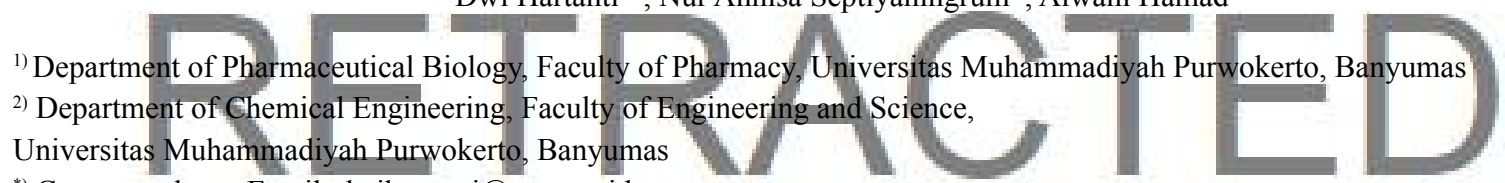 \\ *) Correspondence Email: dwihartanti@ump.ac.id
}

\begin{abstract}
Clove and lemon basil are widely used in Indonesian culinary and known for their antimicrobial properties. This study was designed to identify the chemical constituents of individual clove and lemon basil essential oils and evaluate the effects of their combinations for the preservation of chicken meats. The essential oils were obtained from a steam and water distillation method and their chemical constituents were analyzed with Gas Chromatography-Mass Spectrometer (GC-MS). Their potential preservation effect was evaluated by observing the physical characters of the meats and the reduction of the microbial growth on the meats during 15 days of refrigerated storage. The major constituents of clove essential oil were eugenol, $\beta$-caryophyllene, and $\alpha$-humulene, while those of lemon basil were estragole, linalool, E-citral, and Z-citral. The combination of clove and lemon basil essential oils, particularly at ratios of $1: 1$ and $2: 0.2 \% \mathrm{v} / \mathrm{v}$, capable of delaying the changes of physical characters of the meats until the final day of storage. Those two ratios showed the best reduction in the microbial growth in day 3 and 9 , respectively. This preservation potential might be related to the high proportion of eugenol and citrals in both essential oils.
\end{abstract}

Keywords: Chemical Constituents, Clove, Essential Oils, Natural Food Preservative, Lemon Basil

\section{INTRODUCTION}

Chicken meat is one of the most popular meats and commonly consumed worldwide for being considered as healthier and is frequently more affordable than other meats (Farrell, 2019; OECD-eLibrary, 2019). However, it contains a high amount of water, proteins, and fats that enables the growth of microorganisms on it (FAO, 2019). It is easily spoiled by microorganisms and further has a relatively short shelf life. In order to prolong its shelf life and minimize the risk of foodborne illness and food poisoning, a preservation process is required (Dave and Ghaly, 2011).

Chemical preservation efforts on chicken meat have been evaluated. The applications of chitosan, nisin, and essential oils for the said purpose have gained significant interests (Al-Hijazeen et al., 2016; Alnoman et al., 2017; Raeisi et al., 2016). Essential oils of spices and herbs with profound antimicrobial activity are interesting to be explored further for our familiarity with their taste and aroma in our daily meals. Clove (Syzygium aromaticum (L.) Merr. \& L.M. Perry, Myrtaceae) and lemon basil (Ocimum x africanum Lour., Lamiaceae) are commonly used in Indonesian culinary and potentially applied as a natural preservative of chicken meats.

Clove essential oil has been widely known as an antimicrobial agent against bacteria and fungi (Hamad et al., 2017; Naveed et al., 2013; Sethi et al., 2013). It has been applied in the food preservation model with a moderate to strong efficacy (Hamad and Hartanti, 2015). The lemon basil essential oil has demonstrated antimicrobial activity against a wide array of microorganisms, including the food spoilage ones (Carovic'-Stanko et al., 2010; Kaya et al.,
2008; Khalil, 2013). It also has been applied as natural foods preservative (Gaio et al., 2015; Joshi, 2014).

Although the antimicrobial effects and potential food preservation of both clove and lemon basil essential oils have been described, they were individually evaluated. There were no reports on their use as a combination yet. The combination of some essential oils with weak or moderate antimicrobial activity is considered producing synergistic or mutually reinforcing effects (Bassolé and Juliani, 2012). This synergistic effect is desirable in the application of essential oil for food preservatives since the lower concentration of respective essential oils will not affect the flavor, aroma and reception level of the food. Combining essential oils is expected to increase their antimicrobial activity but also retain the character of the preserved foods (Rialita et al., 2015). This study was conducted to analyze the chemical constituents of individual clove and lemon basil essential oils as well as evaluate the potential of their combinations as the natural preservative of fresh chicken meats.

\section{MATERIALS AND METHODS}

Preparation of plant materials

Leaves of clove and aerial parts of lemon basil were collected from Pemalang and Banyumas, Central Java, Indonesia, respectively. The plant materials were authenticated at the Laboratory of Plant Taxonomy, Universitas Jendral Soedirman, Purwokerto, Central Java, Indonesia. Both were dried under the direct sunlight $(8 \mathrm{am}-3 \mathrm{pm})$ for 4 days.

\section{Extraction of essential oils}

The essential oils of clove and lemon basil were distilled with steam and water distillation as previously conducted 
(Hamad et al., 2017). Each distillation process was run for the average time of $7 \mathrm{~h}$. The remained water in the essential oils was absorbed with $\mathrm{Na}_{2} \mathrm{SO}_{4}$ and stored in a tightly closed amber vial at a temperature of $4^{\circ} \mathrm{C}$ until further analysis.

\section{Identification of chemical constituents of essential oils} Essential oils were analyzed using a hyphenated gas chromatography-mass spectrometer (QP2010 SE, Shimadzu, Japan) utilized a dimethylpolysiloxane column (SH-Rxi-5Sil MS, Shimadzu, Japan). The condition of the separation and ionization of the separated constituents followed a previously reported method (Hartanti et al., 2018). The identification of constituents was conducted by comparing the mass spectrum of each constituent with those available in a spectral library (Wiley 6.0, Wiley Science Solution, USA).

\section{Evaluation of preservation potential of combinations of clove and lemon basil essential oils}

The fresh chicken meats used in this study were obtained from a local market at Purwokerto, Indonesia. The breast meats were cut in size of $1 \times 1 \times 1 \mathrm{~cm}$ and immersed in sterile water at the temperature of $100 \pm 5{ }^{\circ} \mathrm{C}$ for $5 \mathrm{~s}$ to reduce the number of microorganisms on their surface. The preservation potential of the combination of clove and lemon basil essential oils were evaluated by following a previous report (Hartanti et al., 2018). In brief, three different concentration ratios of the combination of clove and lemon basil essential oils $(2: 0.2,1: 1$, and $0.1: 2 \% \mathrm{v} / \mathrm{v})$, along with individual elove and lemon basil essential oils in a concentration of $1 \% \mathrm{v} / \mathrm{v}$, were prepared. They were prepared by dissolving essential oils in the equal volume of dimethyl sulfoxide (DMSO) and making the final volume of $500 \mathrm{ml}$ with sterile water. DMSO in the water at the concentration of $2 \% \mathrm{v} / \mathrm{v}$ was used as the negative control. The cubed chicken meats were immersed in the essential oil preparations for 1 minute and aseptically kept under refrigerated storage with a temperature of $5 \pm 2^{\circ} \mathrm{C}$ for 15 days. The physical characters of the preserved meats and the indirect enumeration of bacterial growth on the meats were carried out in 3 day-interval in day $0,3,6,9,12$, and 15 . On the respective observation days, the bacterial growth on meats was analyzed with an indirect enumeration method, that each cube of meats was put in $25 \mathrm{ml}$ of sterile nutrient broth (NB) medium and then homogenized for a minute. One $\mathrm{ml}$ of suspension was transferred into $9 \mathrm{ml}$ of sterile $\mathrm{NB}$ and then put in an incubator (KS40, IKA, Malaysia) at a temperature of $37^{\circ} \mathrm{C}$ for 24 hours. The optical densities (OD) of cultured bacterial suspensions were recorded with the UV-Vis spectrophotometer (UV-1240, Shimadzu, Japan) at a wavelength of $600 \mathrm{~nm}$. The physical characters of the preserved meats, including odor, texture, and formation of slime were simultaneously evaluated. All the works were replicated 3 times.

\section{Statistical data analysis}

The reduction in the microbial count of cultured bacterial suspensions in NB was calculated by subtracting the value of the ODs obtained from each treatment group with that of the negative control on the same observation day. The differences between the mean of the OD reduction among the treatment groups were analyzed by one-way analysis of variance followed by Duncan's tests with $p$-value $<0.05$ utilized the general procedures of IBM SPSS Statistics 20 (IBM).

\section{RESULTS AND DISCUSSION}

The steam and water distillation of clove and lemon basil dried plant materials produced essential oils with a yield of 0.84 and $0.76 \%$, respectively. There are 17 compounds identified from the clove essential oil, with eugenol, trans- $\beta$-caryophyllene, and $\alpha$-humulene as the main constituents (Table 1, Figure 1). Eugenol is typically the most abundant constituent of clove essential oils. However, the concentration of eugenol is varied according to the source of the clove. A study on one obtained from Lavras, Brazil showed that eugenol $(89.80 \%)$, trans-caryophyllene (5.88\%), and $\alpha$-humulene $(2.30 \%)$ as the major constituents (De-Oliveira et al., 2013). Eugenol was detected in a lower concentration $(75.19 \%)$, along with trans-caryophyllene (18.36\%) and $\alpha$-humulene $(2.73 \%)$ in essential oil distilled from clove leaves collected in Banyumas, Central Java, Indonesia (Hamad et al., 2017).
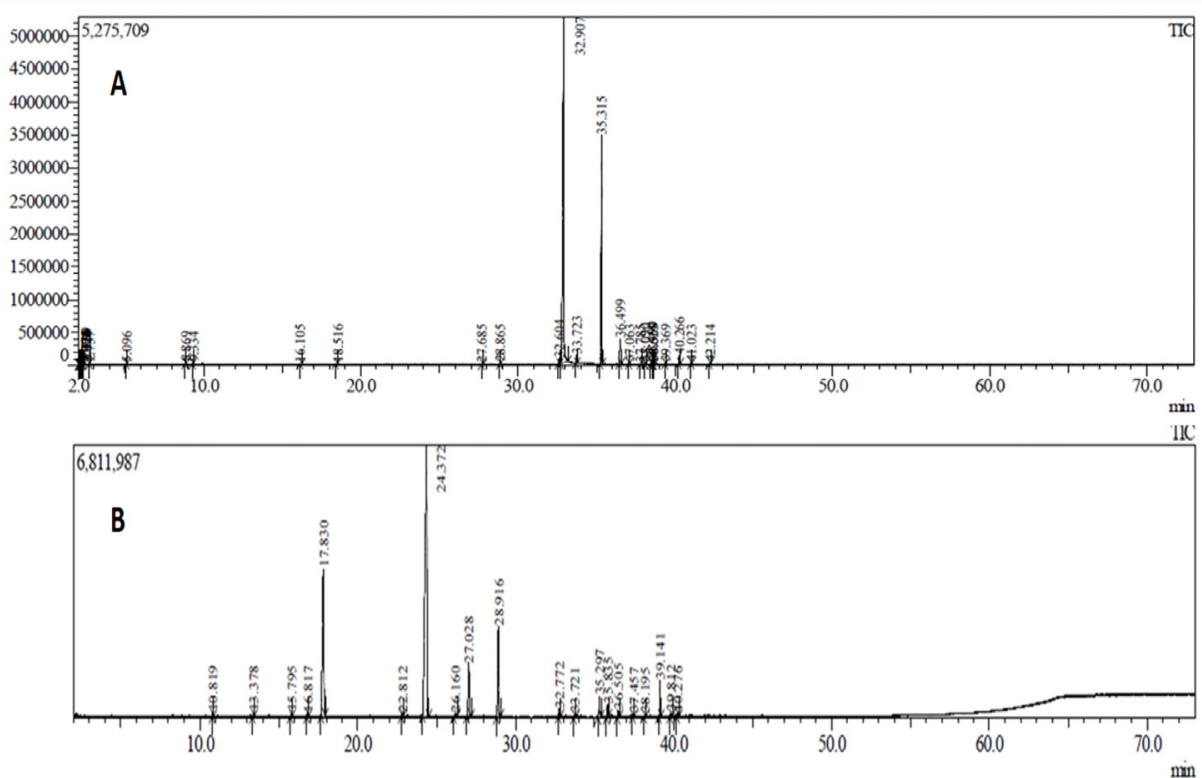

Figure 1. GC-MS chromatogram of (A) clove and (B) lemon basil essential oils 
Lemon basil essential oil constituted of 11 constituents with estragole, linalool L, E-citral and Z-citral as major compounds (Table 1, Figure 1). Our result is following a previously reported study, that estragole, E-citral, and Z-citral were the principal components of lemon basil essential oil collected in Chiang Mai, Thailand (Tangpao et al., 2018). However, the different percentage of each compound in lemon basil essential oil was reported following the different harvesting and post-harvest drying methods of lemon basil aerial parts. Citral (55.0-75.5\%), $\gamma$-bisabolene (2.6-9.5\%), nerol (1.7-8.9\%), geraniol (1.5$6.5 \%$ ), linalool (1.1-6.0\%), and $\beta$-caryophyllene (0.7-3.2\%) were identified as the characteristic constituents of lemon basil essential oil originated from northern India (Padalia et al., 2018). In addition, the presence of E-citral, eugenol $\alpha$-copaene, $\beta$-caryophyllene, $\alpha$-humulene, $\Delta$-cadinene, and caryophyllene oxide were detected in both essential oils used in our study.
In this study, the bacterial growth on the meats during storage was enumerated by an indirect method utilizing OD of the culture of the meats, which was express as the reduction in OD. The more reduction in OD of the culture of the meats in NB of a given sample indicated the presence of fewer bacteria on the chicken meats. The fewer bacteria were resulted from the bacterial growth inhibitory activity of the essential oils. Hence, the more reduction in OD represented better antibacterial properties of a given sample. In general, the OD reduction of the cultured meats treated with the combination of clove and lemon basil essential oils were more than those treated with the single essential oil. In day 3 , the combination of clove and lemon basil essential oils at a concentration ratio of $2: 0.2 \%$ demonstrated the best OD reduction among all groups, while that at $1: 1 \%$ showed the same effect on day 9 (Figure 2).

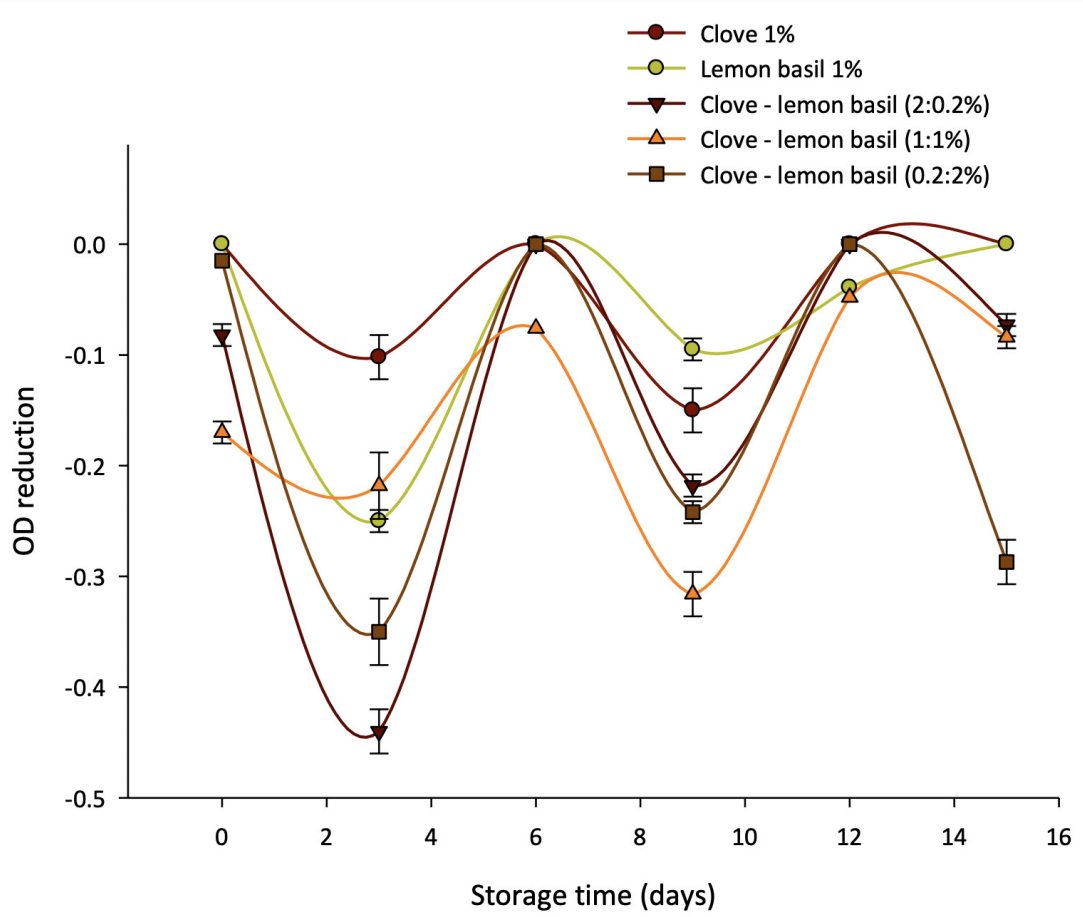

Figure 2. The profile of the reduction in the microbial count by indirect microbial enumeration on the meats during storage

Clove essential oil acts as an antibacterial agent by the mechanism of inducing cell lysis. A study mentioned that both cell wall and membrane of E. coli and B. subtilis showed significant damage after treatment with clove essential oil (Rhayour et al., 2003). Besides, clove oil's antimicrobial activity was also mediated by oxidative stress, loss of motility, and also changes in the expression of virulence-associated genes, as observed in Campylobacter jejuni (Kovács et al., 2016). Until now there is no report on the modes of action of antimicrobial activity of lemon basil essential oil yet. However, when two essential oils were combined, they produced synergism by a mechanism of sequential inhibition of a common biochemical pathway, inhibition of protective enzymes, and enhancement of the uptake of another oil use (Bassolé and Juliani, 2012).
Our result demonstrated that the combination of clove and lemon basil essential oils possessing a better activity in inhibiting the growth of microorganisms on the meats during storage than that of the individual essential oil use. It might be related to the synergistic antimicrobial activity of the individual oils as reported elsewhere. For example, the combination of lemongrass and Kachi grass essential oils was proven to exert synergistic antibacterial effects against Staphylococcus aureus, Listeria monocytogenes, Escherichia aerogenes, and Salmonella typhimurium (Bassolé et al., 2011). Synergism effects were also shown by the combination of essential oils of oregano and basil, oregano and bergamot, as well as basil and bergamot against $S$. aureus (Lv et al., 2011). 
Each compound in a given essential oil contributes differently to its overall antimicrobial activity. Oxygenated compounds are considered possessing a more prominent antimicrobial activity while the hydrocarbons are usually inactive (Chouhan et al., 2017). In our study, lemon basil essential oil contained a higher number of oxygenated compounds than that of the clove. The theoretical relative volume of oxygenated compounds in each concentration ratio of the combination of clove and lemon basil essential oils was calculated to find the relationship between the preservation potentials with their chemical compounds. They were calculated based on the area of the oxygenated compounds in the GC-MS chromatogram and the volume of each essential oils in a given combination. The theoretical relative volume of oxygenated compounds in combinations of both essential oils was found to be higher than in individual cloves or lemon basil essential oil (Figure 3). Aldehydes and phenols usually demonstrated the best antibacterial activity among the oxygenated compounds (ElShenawy et al., 2015). Nearly all oxygenated compounds in clove essential oil were phenols (eugenol) and aldehydes (E-citral), while lemon basil essential oil only contained a much lower fractions eugenol, Z-citral, and E-citral (Table 1). Calculated in the same way as that of oxygenated compounds, the combinations of clove and lemon basil essential oils in ratios of $2: 0.2$ and $1: 1 \% \mathrm{v} / \mathrm{v}$ showed the highest amount of theoretical relative volume of aldehydes and phenols (Figure 3). The theoretical relative volume of antimicrobial-active compounds supported our finding in the enumeration of bacterial growth on the meats. The combination of clove and lemon basil essential oils at a concentration ratio of 2:0.2 and 1:1\% showed the highest theoretical relative volume of oxygenated compounds as well as the best bacterial growth inhibitory activity in day 3 and 9 , respectively.

Table 1. Chemical constituents of clove and lemon basil essential oils

\begin{tabular}{|c|c|c|c|}
\hline \multirow[t]{2}{*}{ Chemical Constituents } & \multirow[t]{2}{*}{ Retention time (min) } & \multicolumn{2}{|c|}{ Area (\%) } \\
\hline & & Clove & Lemon basil \\
\hline 3,3-Dimethylpentane & 2.075 & 0.14 & - \\
\hline 2-Methylhexane & 2.136 & 0.22 & - \\
\hline 2,3-Dimethylpentane & 2.170 & 0.08 & - \\
\hline 3- Methylhexane & 2.209 & 0.21 & - \\
\hline 3-Ethylpentane & 2.301 & 0.17 & - \\
\hline n-Heptane & 2.420 & 0.09 & - \\
\hline Methylcyclohexane & 2.737 & 0.03 & - \\
\hline 1-Ethyl butyl hydroperoxide & 8.869 & 0.05 & - \\
\hline Linalool oxide & 15.795 & - & 0.35 \\
\hline Linalool & 17.830 & - & 18.9 \\
\hline Estragole & 24.372 & - & 55.78 \\
\hline Z-Citral & 27.028 & - & 6.54 \\
\hline E-Citral & 28.916 & 0.05 & 10.06 \\
\hline$\alpha$-Cubebene & 32.604 & 0.56 & - \\
\hline Eugenol & 32.772 & 67.0 & 0.64 \\
\hline$\alpha$-Copaene & 33.721 & 0.56 & 0.15 \\
\hline Trans- $\beta$-caryophyllene & 35.297 & 25.64 & 1.51 \\
\hline$\alpha$-Humulene & 36.505 & 2.66 & 0.45 \\
\hline$\Delta$-Cadinene & 37.063 & 0.07 & 0.11 \\
\hline$\beta$-Farnesene & 37.457 & 0.15 & - \\
\hline Caryophyllene oxide & 40.270 & 0.86 & 0.26 \\
\hline Total area & & 98.54 & 94.75 \\
\hline Total hydrocarbon compounds & & 29.93 & 2.22 \\
\hline Total oxygenated compounds & & 68.61 & 92.53 \\
\hline Total phenol and aldehyde con & npounds & 67.05 & 17.24 \\
\hline
\end{tabular}




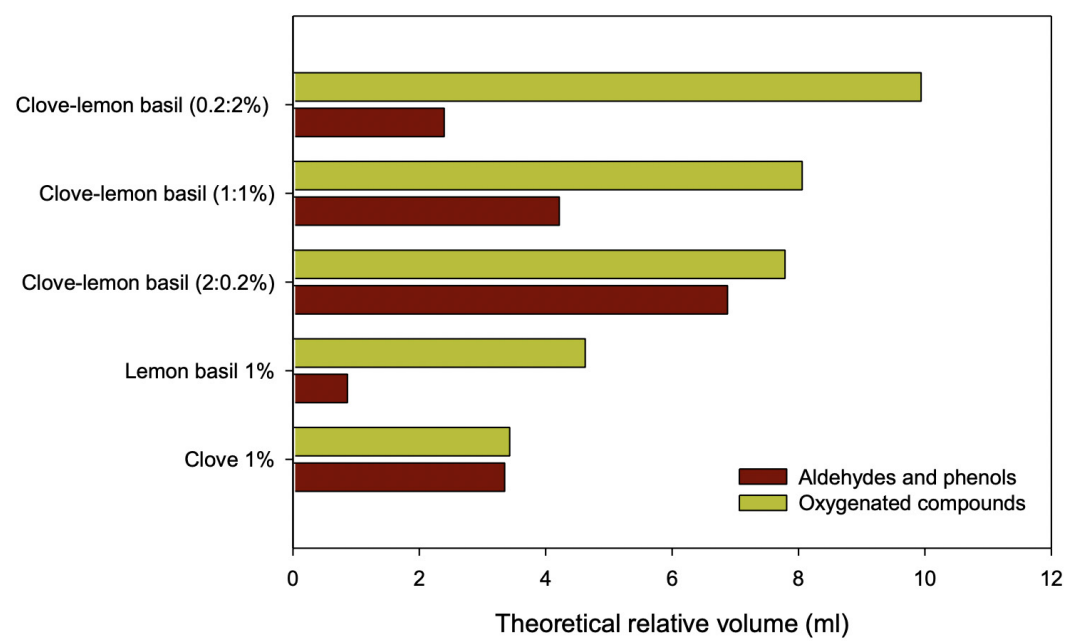

Figure 3. The profile of theoretical relative volume of oxygenated compounds as well as aldehydes and phenols in each concentration ratios of the combination of clove and lemon basil essential oils

The presence of bacteria caused changes in the physical characters of the meats. The bacteria broke proteins and lipids down to obtain nutrients they can use for metabolism. The changes in texture and odor, as well as the slime formation, on the meats, are resulted from this process. The breakdown of the macromolecules leads to the loss of the solid texture of the meats. The products of proteins and lipids digestion process by microorganisms resulted in the putrid odor and formation of slime (Dave and Ghaly, 2011). In this study, the odor and texture of the preserved meats, as well as the formation of slime on their surfaces were evaluated. At the beginning of the study, the odor of the meats was a typical fresh one. They had a solid texture and there was no slime detected. Right after the treatment with samples, the odor of meats in individual essential oil groups was masked with the specific aroma of the oils. The meats treated in the negative control started to smell putrid, softer and showed the presence of slime on day 3. Those preserved with single essential oils were started to change day 9 , that the aromatic clove or lemon basil scents went weaker. The changes with the meat texture and slime formation were also observed. The changes of the physical characters were observed later in meats treated with the combination of the essential oils. Combinations of clove and lemon basil essential oils, particularly at the ratios of $1: 1$ and $2: 0.2 \% \mathrm{v} / \mathrm{v}$, were capable of preserving the initial characters of the meats until the final day of the storage (Figure 4).

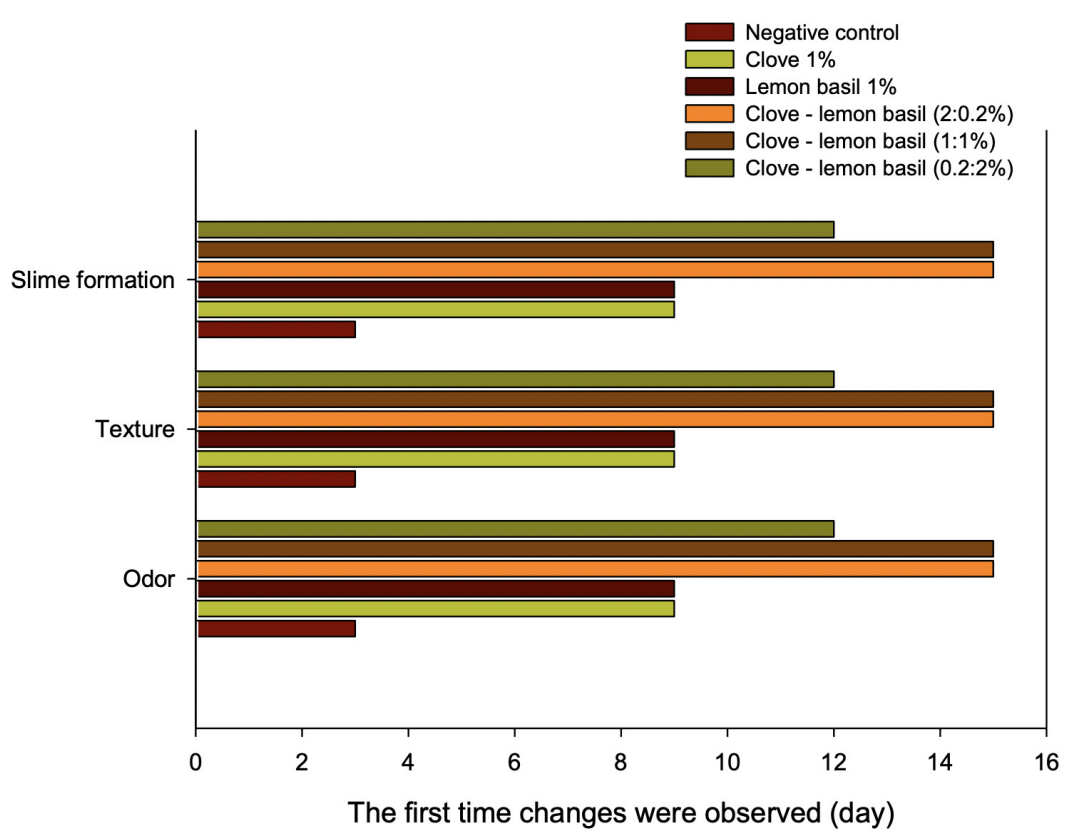

Figure 4. The effects of combinations of clove and lemon basil essential oils to the first day when the initial changes in physical characters of the preserved meats were observed 
The capacity of the samples in delaying the changes of physical characters of the meat represents their respective preservation potential. It was calculated by comparing the first day when any physical characters of meats treated with given samples were observed to those in negative control groups. Both individual cloves and lemon basil essential oils showed the preservation potential for 6 days. The combinations of those oils in all concentration ratios used were capable of providing a longer time of protection before one or more characters of chicken meats were changed than those in the individual uses. The combination of essential oils of clove and lemon basil, particularly in concentration ratios of 2:0.2 and 1:1\% v/v, provided the best preservation potential for the meats during storage (Figure 5).

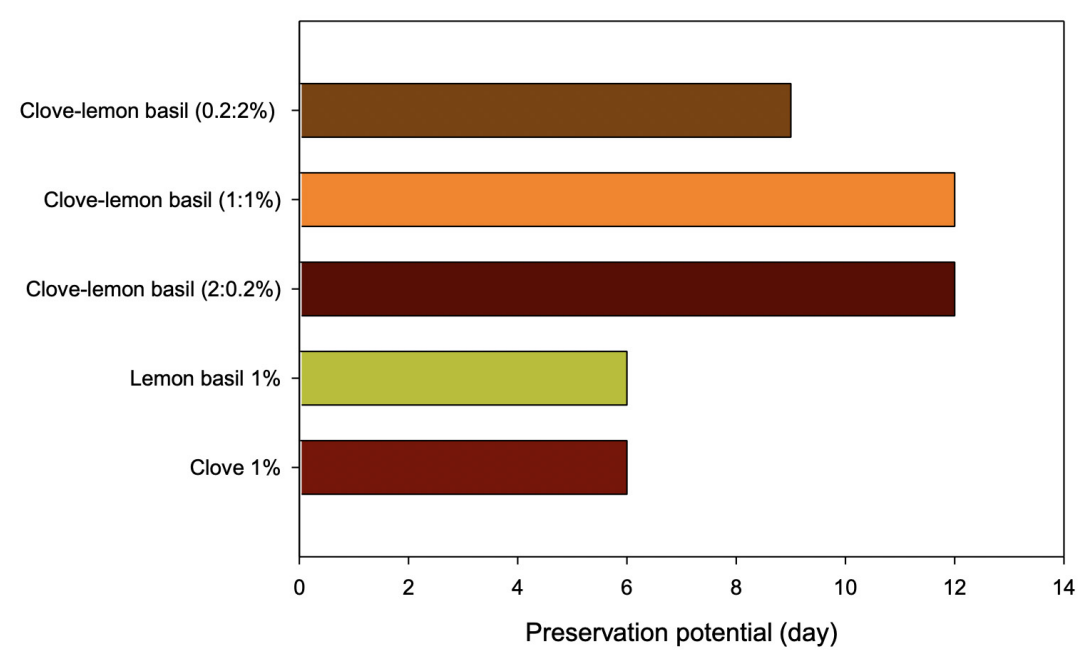

Figure 5. The effect of combinations of clove and lemon basil essential oils to their preservation potential for the chicken meats

When the results of the evaluation of reduction in the microbial count, the theoretical relative volume of antimicrobial-active compounds, and preservation potential were taken into account, the combinations of clove and lemon basil essential oils demonstrated a better preservation potential compared to the individual oil use. At the ratios of 2:0.2 and 1:1\% v/v, it showed the best reduction in bacterial growth on those meats at day 3 and 9, respectively, as well as delayed their physica changes for 12 days at the refrigerated storage. This result confirms previous reports on the synergistic effects of the combination of essential oils in food preservation efforts (Hyldgaard et al, 2012). The similar action was also shown by the combination of lemongrass and onion essential oils, which their use caused a greater reduction in the growth of E. coli, L. monocytogenes, and S. aureus on the spinach and romaine lettuce leaves compared to the individual use of each essential oil (Ortega-Ramirez et al., 2017). In addition, the better acceptability of the use of essential oil combinations as a natural food preservative has been reported. The application of a combination of Chinese cinnamon and common cinnamon essential oils to the cooked meats was organoleptically acceptable up to the concentration of $0.05 \% \mathrm{v} / \mathrm{w}$ of the meats (Ghabraie et al., 2016).

\section{CONCLUSION}

The combinations of essential oils of cloves and lemon basil at ratios of $1: 1$ and $2: 0.2 \% \mathrm{v} / \mathrm{v}$ exerted the best chicken meat preservation potential. They were capable of reducing the microbial count on the meats and delaying the changes in physical characters of chicken meats for 12 days during refrigerated storage. This meat preservation effects might be related to the presence of high fractions of oxygenated compounds, mainly eugenol, Z-citral, and E-citral in both clove and lemon basil essential oils

\section{REFERENCES}

Al-Hijazeen, M., Lee, E.J., Mendonca, A., Ahn, D.U., 2016. Effect of oregano essential oil (Origanum vulgare subsp. hirtum) on the storage stability and quality parameters of ground chicken breast meat. Antioxidant 5(2): article E18.

Alnoman, M., Udompijitkul, P. and Sarker, M.R. .2017. Chitosan inhibits enterotoxigenic Clostridium perfringens type $\mathrm{A}$ in growth medium and chicken meat. Food Microbiology. 64: $15-22$.

Bassolé, I.H.N. and Juliani, H.R. 2012. Essential oils in combination and their antimicrobial properties. Molecules. 1: 3989-4006.

Bassolé, I.H.N., Lamien-Meda, A., Bayala, B., Obame, L.C., Ilboudo, A.J., Franz, C., Novak, J .2011. Chemical composition and antimicrobial activity of Cymbopogon citratus and Cymbopogon giganteus essential oils alone and in combination. Phytomedicine. 18(12): 1070-1074.

Carovic'-Stanko, K., Orlic', S., Politeo, O., Strikic', F., Kolak, I., Milos, M. and Satovic, Z. 2010. Composition and antibacterial activities of essential oils of seven Ocimum taxa. Food Chemistry. 119(1): 196-201.

Chouhan, S., Sharma, K. and Guleria, S. 2017. Antimicrobial activity of some essential oils - present status and future perspectives. Medicines (Basel). 4(3): article 58.

Dave, D. and Ghaly, A.E. 2011. Meat spoilage mechanism and preservation techniques: A critical review. American Journal of Agricultural and Biological Sciences. 6(4): 486-510.

De-Oliveira, T.L.C., Cardoso, M. d C., Soares, R. d A., Ramos, E.M., Piccoli, R.H. and Tebaldi, V.M.R. 2013. Inhibitory activity of Syzygium aromaticum and Cymbopogon citratus 
(DC.) Stapf. essential oils against Listeria monocytogenes inoculated in bovine ground meat. Brazilian Journal of Microbiology. 44(2): 356-365.

El-Shenawy, M.A., Baghdadi, H.H. and El-Hosseiny, L.S. 2015. Antibacterial activity of plants essential oils against some epidemiologically relevant food-borne pathogens. The Open Public Health Journal. 8: 30-34.

FAO. 2019. Composition of Meat. Animal Production and Health. available at: http://www.fao.org/ag/againfo/themes/en/meat/ backgr_composition.html (accessed 14 February 2019).

Farrell, D. 2019. The role of poultry in human nutrition: The nutritional benefits of chicken meat compared with other meats. Food and Agriculture Organization of the United Nations Poultry Development Review.

Gaio, I., Saggiorato, A.G., Treichel, H., Cichoski, A.J., Astolfi, V., Cardoso, R.I., Toniazzo, G., et al. 2015. Antibacterial activity of basil essential oil (Ocimum basilicum L.) in Italian-type sausage. Journal of Consumer Protection and Food Safety. 10(4): 323-329.

Ghabraie, M., Vu, K.D., Tata, L., Salmieri, S. and Lacroix, M. 2016. Antimicrobial effect of essential oils in combinations against five bacteria and their effect on sensorial quality of ground meat. LWT - Food Science and Technology. 66: 332339.

Hamad, A. and Hartanti, D. 2015. The use of essential oil o Clove (Syzygium aromaticum) as Tofu's natural preservative. Farmasains. 2(6): 289-294.

Hamad, A., Mahardika, M.G.P., Yuliani, I. and Hartanti, D. 2017. Chemical constituents and antimicrobial activities of essential oils of Syzygium polyanthum and Syzygium aromaticum. Rasayan Journal of Chemistry. 10(2): 564-569.

Hartanti, D., Haqqi, M.Z.U. and Hamad, A. 2018. Potency of combination of essential oils of Ginger and Lemongrass as fresh chicken meat natural preservative. Advanced Science Letters. 24(1): 91-94.

Hyldgaard, M., Mygind, T., Meyer, R.L. and Debabov, D. 2012. Essential oils in food preservation: mode of action, synergies, and interactions with food matrix components. Frontiers in Microbiology. 3(12): $1-24$.

Joshi, R.K. 2014. Chemical composition and antimicrobial activity of the essential oil of Ocimum basilicum L. (sweet basil) from Western Ghats of North West Karnataka, India. Ancient Science of Life. 33(3): 151-156.

Kaya, I., Yigit, N. and Benli, M. 2008. Antimicrobial activity of various extracts of Ocimum basilicum L. and observation of the inhibition effect on bacterial cells by use of scanning electron microscopy. African Journal of Traditional and Complimentary Medicines. 5(4): 363-369.

Khalil, A. 2013. Antimicrobial activity of ethanolic extracts of Ocimum basilicum leaf from Saudi Arabia. Biotechnology. 12: 61-64.

Kovács, J.K., Felso, P., Makszin, L., Pápai, Z., Horváth, G., Ábrahám, H., Palkovics, T., Böszörményi, A., Emody, L. and Schneider, G. 2016. Antimicrobial and virulencemodulating effects of clove essential oil on the foodborne pathogen Campylobacter jejuni. Applied and Environmental Microbiology. 82(20): 6158-6166.
Lv, F., Liang, H., Yuan, Q. and Li, C. 2011. In vitro antimicrobial effects and mechanism of action of selected plant essential oil combinations against four food-related microorganisms. Food Research International. 44(9): 3057-3064.

Naveed, R., Hussain, I., Tawab, A., Tariq, M., Rahman, M., Hameed, S., Mahmood, M.S., et al. 2013. Antimicrobial activity of the bioactive components of essential oils from Pakistani spices against Salmonella and other multi-drug resistant bacteria. BMC Complementary and Alternative Medicine. 13(1): 265.

OECD. 2019. Meat consumption (indicator). OECD Data, available at: https://doi.org/10.1787/fa290fd0-en. (accessed 14 February 2019)

Ortega-Ramirez, L.A., Silva-Espinoza, B.A., Vargas-Arispuro, I., Gonzalez-Aguilar, G.A., Cruz-Valenzuela, M.R., Nazzaro, F. and Ayala-Zavala, J.F. 2017. Combination of Cymbopogon citratus and Allium cepa essential oils increased antibacterial activity in leafy vegetables. Journal of Science of Food and Agriculture. 97(7): 2166-2173

Padalia, R.C., Singh, V.R., Bhatt, G., Chauhan, A., Upadhyay, R.K., Verma, R.S. and Chanotiya, C.S. 2018. Optimization of harvesting and post-harvest drying methods of Ocimum africanum Lour. for production of quality essential oil. Journal of Essential Oil Research. 30(6): 437-443.

Raeisi, M., Tabaraei, A., Hashemi, M. and Behnampour, N. 2016. Effect of sodium alginate coating incorporated with nisin, Cinnamomum zeylanicum, and rosemary essential oils on microbial quality of chicken meat and fate of Listeria monocytogenes during refrigeration. International Journal of Food Microbiology. 238: 139-145.

Rhayour, K., Bouchikhi, T., Tantaoui-Elaraki, A., Sendide, K. and Remmal, A. 2003. The mechanism of bactericidal action of oregano and clove essential oils and of their phenolic major components on Escherichia coli and Bacillus subtilis. Journal of Essential Oil Research 15(4): 286-292.

Rialita, T., Rahayu, P.W., Nuraida, L.and Nurtama, B. 2015. Aktivitas antimikroba minyak esensial jahe merah (Zingiber officinale var. Rubrum) dan lengkuas merah (Alpinia purpurata K. Schum) terhadap bakteri patogen dan perusak pangan. Agritech. 35(1): 43-53

Sethi, S., Dutta, A., Gupta, B.L. and Gupta, S. 2013. Antimicrobial activity of spices against isolated food borne pathogens. International Journal of Pharmacy and Pharmaceutical Sciences. 5(1): 5-7.

Tangpao, T., Chung, H.-H. and Sommano, S.R. 2018. Aromatic profiles of essential oils from five commonly used Thai basils. Foods 7(11): article E175. 